\title{
Pengaruh Ukuran Dewan Komisaris, Independensi Dewan Komisaris, dan Komite Audit terhadap Corporate Social Responsibility Disclosure dengan Profitabilitas sebagai Variabel Moderasi
}

\author{
Bintang Satria Herizona ${ }^{\left.1^{*}\right)}$, Indah Yuliana ${ }^{2)}$ \\ 1*), 2), Manajemen, Fakultas Ekonomi, Universitas Islam Negeri Maulana Malik Ibrahim, \\ Malang \\ E-mail:bintangherizona@gmail.com ${ }^{1 *}$
}

\begin{abstract}
ABSTRAK
Tujuan dari penelitian ini untuk menguji pengaruh parsial dan simultan variabel ukuran dewan komisaris, independensi dewan komisaris, dan komite audit terhadap corporate social responsibility disclosure serta pengaruh dari adanya penambahan variabel profitabilitas sebagai variabel moderasi. Sampel penelitian menggunakan sebanyak 38 perusahaan sektor industri dasar dan kimita tahun 2016-2019 yang ditentukan berdasarkan purposive sampling yang sudah ditetapkan dan analisis penelitian mengunakan moderated regression analysis. Hasil penelitian didapatkan bahwa secara parsial variabel ukuran dewan komisaris dan independensi dewan komisaris memiliki pengaruh yang signifikan. Sementara sercara simultan variabel yang digunakan memiliki pengaruh yang signifikan. Pada uji moderasi return on asset didapatkan hasil bawah variabel tersebut tidak mampu memoderasi hubungan antara variabel independen dengan variabel dependen sedangkan pada uji moderasi return on equity didapatkan hasil bahwa variabel tersebut mampu memoderasi hubungan variabel ukuran dewan komisaris dengan corporate social responsibility disclosure.
\end{abstract}

Kata Kunci: Independensi Dewan Komisaris; Komite Audit; Profitabilitas; Pengungkapan Tanggung Jawab Sosial; Ukuran Dewan Komisaris

\begin{abstract}
The purpose of this study is to examine the partial and simultaneous effect of the size of board commissioners, the independence of board commissioners, and the audit committee on corporate social responsibility disclosure and the effect of the addition of profitability variable as a moderating variable.the research sample used 38 companies in the basic and chemical industry sectors in 2016-2019 which were determined based on predetermined purposive sampling and reseach analysis using moderated regression analysis. The results showed that partially the variable size of board commissioners and the inpendence of board commissioners had a significant effect. While simultaneously the variables used have a significant effect. In the moderation test of return on assets, the result show that the variable is not able to moderate the relationship between the independent variable and the dependent variable, while in the moderation test of return on equity, it was found that variable was able to moderate the relationship between the size of board commissioners variable and the corporate social responsibility disclosure
\end{abstract}

Keywords: Independence of the board of commissioners; Audit Committee; Profitability; Corporate Social Responsibility Disclosure; Size of the board commissioners 


\section{PENDAHULUAN}

Kewajiban yang diperuntukkan perusahaan atau badan usaha sebagaimana berdasarkan UU No. 40 Tahun 2007 adalah Corporate Social Responsibility. Namun, sering kali terdapat penyelewengan yang dilakukan perusahaan dalam melaksanakan kewajibannya tersebut. Suastha (2016) menyebutkan dalam jurnal Centre of Governance, Institutions and Organizations bahwa kualitas pelaksanaan tanggung jawab sosial di Indonesia rendah dibanding perusahaan di negara Thailand. Hal tersebut diketahui dari perolehan nilai yang dicapai negara Thailand dari total keseluruhan 100 poin mendapat nilai 56,8 sementara Indonesia mendapatkan nilai sebesar 48,4. Sehubungan dengan jurnal tersebut, dijelaskan bahwa yang menjadi peran penting dalam memastikan pelaporan tanggung jawab sosial perusahaan yang berkelanjutan adalah pemenrintah dan stakeholder.

Peran pemerintah dalam kegiatan tanggung jawab sosial perusahaan antara lain meurmuskan kebijakan yang ramah terhadap pasar, sumber daya yang partisipatif dan memberikan sokongan politik bagi pelaku Corporate Social Responsibility, menciptakan stimulus dan meningkatkan kemampuan perusahaan (Yanto, 2012). Di Indonesia, pemenuhan tanggung jawab sosial perusahaan memerlukan sokongan pemerintah daerah, kejelasan hukum dan jaminan keteraturan sosial. Selain itu, pemerintah berperan dalam mengkoordinasikan penanganan krisis melalui Corporate Social Responsibility serta memfasilitasi, menyokong serta memberikan komplimen pada perusahaan yang ikut serta dalam kegiatan ini. Pemerintah perlu menilik hubungan antara pebisnis dengan kelompok lainnya supaya tercipta sistem interaksi lebih seimbang dan mencegah penyelewengan atau mengancam salah satu pihak (Yanto, 2012).

Selain itu, peran stakeholder yang ada di dalam suatu perusahaan perlu ditingkatkan guna memperbaiki kualitas Corporate Social Responsibility Disclosure yang dilaksanakan. Hutapea dan Malau (2018); Mohammadi, et al (2020); Nazwir, et al (2016); Yusran, et al (2018); Pasaribu, et al (2015); Restu, et al (2017); Rudyanto dan Siregar (2017); Thasya, et al (2020) dan Wiyuda dan Pramono (2017) meneliti hubungan ukuran dewan komisaris dengan Corporate Social Responsibility Disclosure mengungkapkan apabila perusahaan mempunyai jumlah atau komposisi dewan komisaris yang besar dapat meningkatkan kinerja dalam melakukan monitoring dengan lebih maksimal sehingga diharapkan hal tersebut dapat meningkatkan penungkapan tanggung jawab sosial yang dilakukan. Sementara itu, pentingnya eksistensi dewan komisaris independen dalam perusahaan memiliki fungsi yang krusial guna meningkatkan Corporate Social Responsibility Disclosure (Habbash, 2016). Menurut Sunarsih dan Nurhikmah (2017) dewan komisaris independen mempunyai fungsi 
untuk menempatkan kepentingan perusahaan diatas kepentingan lainnya, seandainya pemimpin perusahaan hanya berorientasi pada kepentingan pemegang saham saja tentu hak tersebut akan membuat kegiatan tanggung jawab sosial yang dilakukan terkesan hanya untuk memenuhi regulasi semata. Hasil penelitian juga didukung oleh Fatimah, et al (2016); Pasaribu, et al (2015) dan Mohammadi, et al (2020).

Selanjutnya, keberadaan komite audit memiliki peran yang krusial dalam peningkatan pengungkapan tanggung jawab sosial. Komite audit berfungsi untuk menetapkan perusahaan telah memenuhi dan mematuhi hukum serta memastikan korporasi menerapkan aktivitas usahanya secara teratur dan bermoral sehingga dapat mendorong Corporate Social Responsibility Disclosure secara lebih luas (Leksono dan Butar, 2018). Fadlillah dan Harymawan (2018); Fatimah, et al (2016); Mohammadi, et al (2020); Nurfadilah dan Sagara (2015); Restu, et al (2017) dan Pernamasari (2019) mendukung argumen tersebut.

Berdasarkan jabaran diatas, keluasan Corporate Social Responsibility Disclosure dibarengi oleh peningkatan kesadaran dewan perusahaan dalam melakukan kewajibannya guna tumbuh berkembang secara berkelanjutan dan juga peranan pemerintah sebagai pihak yang membuat regulasi. Kemudian penambahan variabel profitabilitas dimaksudkan untuk memberikan suatu gagasan bahwa diduga hubungan antara Good Corporate Governance diproksikan kedalam ukuran dewan komisaris, independensi dewan komisaris dan komite audit dengan Corporate Social Responsibility Disclosure diperkuat atau diperlemah oleh faktor lain yang sifatnya kondisional. Sumbangan pemikiran bagi perusahaan mengenai pentingnya Good Corporate Governance, profitabilitas serta Corporate Social Responsibility Disclosure adalah harapan peneliti untuk penelitian ini.

\section{Teori Stakeholder}

Yusuf (2017) menjabarkan bahwa teori Stakeholder merujuk pada sebuah argumen yang menyatakaan bahwa perusahaan memiliki tanggung jawab secara penuh pada seluruh stakehoder. Tujuan utama teori ini untuk menunjang peran manajer dalam memahami akan lingkungan stakeholder-nya dan melaksanakan penanganan secara efektif diantara lingkungan sekitar dengan perusahaan (Khasanah, 2020).

\section{Teori Agency}

Teori Agency berpandangan apabila manajer perusahaan adalah agen shareholder yang berlaku penuh kesadaran diatas kepentingan pribadi. Konsep teori ini berdasarkan pada permasalahan keagenan yang timbul saat pihak principal dan agent mempunyai ketidaksamaan kepentingan maka akan memunculkan suatu masalah yang disebut agency conflict (Furi, 2020). 


\section{Good Corporate Governance}

Aturan yang dipakai untuk mengelola korporasi dengan lebih efektif dan efisien untuk menciptakan value added kepada seluruh pemangku kepentingan adalah definisi yang diutarakn oleh Sutedi (2011). Dalam konsep ini ada beberapa hal yang diperhatikan, yaitu: pertama, pemegang saham (shareholder) mendapat informasi dengan cepat, tepat dan transparan. Kedua, kewajiban perusahaan mengungkapkan mengenai informasi perusahaan kepada stakeholder-nya..

\section{Corporate Social Responsbility}

Gassing (2016) menyebutkan bahwa Corporate Social Responsibility didefinisikan sebagai bentuk kewajiban perusahaan dalam peningkatan kesejahteraan stakeholder-nya dan mengalokasikan sumber daya yang ada. Sementara Corporate Social Responsibility Disclosure didefinisikan sebagai pengeluaran informasi ditujukan pada seluruh stakeholder tujuannya agar perusahaan menyampaikan tanggung jawab sosialnya (Nurfadilah dan Sagara, 2015).

\section{Profitabilitas}

Profitabilitas dapat diartikan sebagai tolak ukur para manajer perusahaan dalam menjalankan perusahaan. Profitabilitas dihitung dengan berbagai rasio, antara lain laba operasi, laba bersih, Return On Equity dan Return On Asset (Wahyuandari, 2015).

\section{PENGEMBANGAN HIPOTESIS}

\section{Pengaruh Ukuran Dewan Komisaris Terhadap Corporate Social Responsibility Disclosure}

Dalam agency theory disebutkan bahwa terdapat biaya keagenan yang timbul sebagai akibat benturan kepentingan antara principal perusahaan dengan agent, dalam hal ini, dewan komisaris disebut sebagai wakil investor. Dengan hak dan wewenangnya maka akan mendorong manajemen dalam pengungkapan informasi-informasi perusahaan (Pasaribu, et al (2015). Penelitian Hutapea dan Malau (2018) menyebutkan ukuran dewan komisaris memiliki hubungan signifikan pada Corporate Social Responsibility Disclosure. Hal tersebut juga didukung Mohammadi, et al (2020); Nazwir, et al (2016); Yusran, et al (2018); Restu, et al (2017); Rudyanto dan Siregar (2017); Thasya, et al (2020) dan Wiyuda dan Pramono (2017). Maka hipotesis pertama penelitian dirumuskan dibawah ini:

H1: Ukuran Dewan Komisris berpengaruh signifikan terhadap Corporate Social Disclosure 


\section{Pengaruh Independensi Dewan Komisaris Terhadap Corporate Social Responsibility} Disclosure

Asumsi dari teori keagenan adalah keistimewaan tertentu dewan komisaris dapat mempengaruhi kemampuannya untuk memonitor, memberikan imbauan pada para manajer serta mempengaruhi performa perusahaan. Dan salah satu keistimewaan tersebut adalah dewan komisaris independen. Dewan ini dianggap sebagai salah satu instumen dalam memonitor integritas manajemen yang kedepannya dapat mendorong keluasan informasi pada tanggung jawab sosialnya (Pasaribu, et al (2015).

Penelitian Fatimah, et al (2016) menyebutkan independensi dewan komisaris berpengaruh signifikan pada Corporate Social Responsibility Disclosure. Sejalan dengan penelitian Pasaribu, et al (2015); Habbash (2016); Mohammdi, et al (2020) dan Nazwir, et al (2016). Maka hipotesis kedua penelitian dirumuskan dibawah ini:

H2: Independensi Dewan Komisaris berpengaruh signifikan terhadap Corporate Soial Responsibility Disclosure

\section{Pengaruh Komite Audit Terhadap Corporate Social Responsibility Disclosure}

Teori agensi menyebutkan bahwa timbulnya biaya keagenan dapat terjadi apabila ketidaksinkronya kepentingan antara principal dan agent dalam suatu perusahaan. Untuk meminimalisir biaya keagenan dibentuklah komite audit. Komite audit dipandang mampu menjamin perusahaan mengikuti dan mematuhi semua peraturan yang ada serta menjamin perusahaan melaksanakan usahanya secara benar dan bermoral sehingga dapat meningkatkan keluasan Corporate Social Responsibility Disclosure (Leksono dan Butar, 2018). Penelitian Nurfadilah dan Sagara (2015) menyebutkan komite audit berpengaruh signifikan pada Corporate Social Responsibility Disclosure. Sejalan dengan penelitian Fadlillah dan Harymawan (2018); Fatimah, et al (2016); Mohammadi, et al (2020); Nurfadilah dan Sagara (2015); Restu, et al (2017) dan Pernamasari (2019). Maka hipotesis ketiga penelitian dirumuskan dibawah ini:

H3: Komite Audit berpengaruh signifikan terhadap Corporate Social Responsibility Disclosure

Pengaruh Ukuran Dewan Komisaris, Independensi Dewan Komisaris dan Komite Audit Secara Simultan Terhadap Corporate Social Responsibility Disclosure

Teori keagenan membahas mengenai pentingnya pembagian antara manajemen dari pemilik perusahaan (Thasya, et al (2020). Pembagian atau pemisahan tersebut terjadi dari adanya perbedaaan kepentingan antara principal dan agent sehingga memunculkan agency cost (Hutapea dan Malau, 2018). Berdasarkan hal tersebut dewan komisaris yang dipandang 
sebagai mekanisme tertinggi dalam memonitor aktivitas manajemen yang dapat meminimalisir masalah keagenan. Sementara dewan komisaris independen dibutuhkan guna memajukan independensi dewan komisaris pada kepentingan shareholder dan menempatkan relevansi perusahaan sebenar-benarnya di atas kepentingan lain sehingga diharapkan dewan komisaris dapat bekerja secara objektif dan dapat menaungi semua pemangku kepentingan dan dapat memperluas Corporate Social Responsibility Disclosure (Hutapea dan Malau, 2018).

Di sisi lain, komite audit disusun oleh dewan komisaris yang berperan sebagai pembantu dewan komisaris yang tugasnya menjamin perusahaan telah menerapkan dan menaati peraturan yang berlaku sehingga mampu memperluas Corporate Social Responsibility Disclosure (Leksono dan Butar, 2018). Dalam penelitian Restu, et al (2017) yang meneliti ukuran dewan komisaris, independensi dewan komisaris dan komite audit bersama-sama berpengaruh signifikan pada Corporate Social Responsibility Disclosure. Maka hipotesis keempat penelitian dirumuskan dibawah ini:

H4: Ukuran Dewan Komisaris, Independensi Dewan Komisaris dan Komite Audit secara simultan berpengaruh signifikan terhadap Corporate Social Responsibility Disclosure.

Profitabilitas Mampu Memoderasi Hubungan Antara Ukuran Dewan Komisaris, Independensi Dewan Komisaris dan Komite Audit dengan Corporate Social Responsibility Disclosure

Perseroan umumnya merupakan badan usaha yang diawasi dan dijalankan oleh orang yang terampil dan berkeahlian profesional agar tujuan perusahaan dapat tercapai. Performa perusahaan menggambarkan keberhasilan atas pelaksanaan fungsi-fungsi keuangan, hal tersebut dapat diketahui salah satunya dengan melihat tingkat profitabilitas. Dalam mencapai tujuan tersebut diperlukannya Good Corporate Governance. GCG didefnisikan sebagai program yang digunakan untuk mengontrol perusahaan, tujuannya meningkatkan nilai shareholder serta menaungi para stakeholder perusahaan seperti kreditor, konsumen, supplier, pemerintah, masyarakat dan pihak lainnya.

Dalam penelitian Sarafina dan Saifi (2017) menyebutkan bahwa terdapat hubungan yang signifikan antara Good Corporate Governance (yang diproksikan kedalam ukuran dewan komisaris dan komite audit secara simultan) terhadap profitabilitas. Hubungan antara profitabilitas denganCorporate Social Responsibility Disclosure dapat dijelaskan dengan dua perspektif. Perspektif pertama menyebutkan bahwa apabila keuntungan semakin tinggi maka pengeluaran informasi tanggung jawab sosial semakin banyak. Didasarkan pada laba yang tinggi, semakin banyak pula aktvitas tanggung jawab sosial yang dapat dijalankan. Sementara 
perspektif kedua adalah semakin rendah keuntungan yang diperoleh maka semakin banyak pula aktivitas tanggung jawab sosial yang dijalankan. Karena, perusahaan ingin menunjukkan motifnya dengan cara menunjukkan citra baiknya agar investor semakin percaya kepada perusahaan dalam hal menanamkan dananya (Leksno dan Butar, 2018).

Penelitian Nazwir, et al (2016) menyebutkan bahwa terdapat pengaruh yang signifikan antara profitabilitas terhadap Corporate Social Responsibility Disclosure. Dalam penelitianpenilitan lain seperti pada penelitian Kartini, et al (2019); Sarafina dan Saifi (2017; Wiyuda dan Pramono (2017); Leksono dan Butar (2018); Nazwir, et al (2016) dan Saputra (2016) menyebutkan bahwa profitabilita berpengaruh signifikan pada Corporate Social Responsibility Disclosure. Maka hipotesis kelima penelitian dirumuskan dibawah ini:

H5a: Return On Asset mampu memoderasi hubungan antara Ukuran Dewan Komisaris dengan Corporate Social Responsibility Disclosure

H5b: Return On Asset mampu memoderasi hubungan antara Independensi Dewan Komisaris dengan Corporate Social Responsibility Disclosure

H5c: Return On Asset mampu memoderasi hubungan antara Komite Audit dengan Corporate Social Responsibility Disclosure

H5d: Return On Equity mampu memoderasi hubungan antara Ukuran Dewan Komisaris dengan Corporate Social Responsiblity Disclosure

H5e: Return On Equity mampu memoderasi hubungan antara Independensi Dewan Komisaris dengan Corporate Social Responsibility Disclosure

H5f: Return On Equity mampu memoderasi hubungan antara Komite Audit dengan Corporate Social Responsibility Disclosure

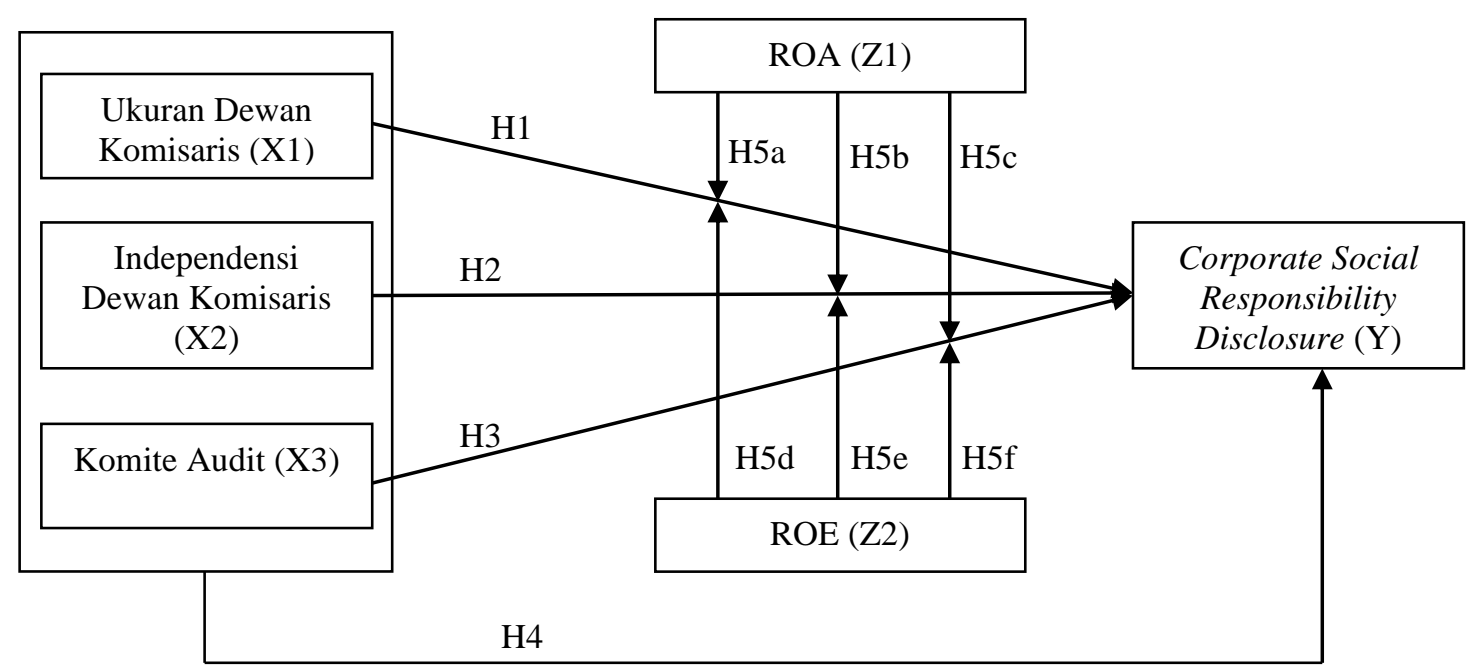

Gambar 1. Kerangka Konseptual 


\section{METODE PENELITIAN}

\section{Populasi dan Sampel}

Sugiyono (2012) mendefinisikan populasi sebagai generalisasi wilayah mencakup atas subyek atau obyek yang memiliki keunggulan dan kriteria tertentu. Sementara sampel itu sendiri adalah bagian kecil dari populasi. Purposive sampling dipakai sebagai metode pengambilan sampel penelitian yang dirumuskan dibawah ini:

Tabel 1. Kriteria Sampel

\begin{tabular}{l|c}
\hline \multicolumn{1}{c}{ Keterangan } & Jumlah Perusahaan \\
\hline $\begin{array}{l}\text { Populasi perusahaan sektor industri dasar dan kimia } \\
\text { tahun 2016-2019 }\end{array}$ & 78 \\
$\begin{array}{l}\text { Perusahaan yang tidak menerbitkan laporan } \\
\text { tahunan secara lengkap } \\
\begin{array}{l}\text { Perusahaan yang mengalami kerugian selama tahun } \\
\text { pengamatan }\end{array}\end{array}$ \\
\multicolumn{1}{c}{ Jumlah Sampel Perusahaan }
\end{tabular}

\section{Data dan Sumber Data}

Data sekunder dipakai dalam penelitian ini. Sunyoto (2013) menjelaskan data sekunder sebagai data yang berasal dari catatan perusahaan yang telah ada dan dari berbagai sumber lain. Data tersebut berupa laporan tahunan/laporan keberlanjutan perusahaan industri dasar dan kimia tahun 2016 s/d 2019 yang didapat dari www.idx.co.id dan masing-masing laman perusahaan.

\section{Teknik Pengumpulan Data}

Studi pustaka dan dokumentasi digunakan untuk memperoleh data penelitian. Studi pustaka dikerjakan dengan cara membaca literasi yang terkait dengan pentanyaan penelitian. Sementara metode dokumentasi dikerjakan dengan meninjau informasi yang ada dalam laporan tahunan/laporan keberlanjutan perusahaan yang digunakan sebagai sampel penelitian (Khasanah, 2020). 


\section{Definisi Operasional Variabel}

Tabel 2. Definisi Operasional Variabel

\begin{tabular}{|c|c|c|c|}
\hline Variabel & Definisi & Pengukuran & Keterangan \\
\hline $\begin{array}{l}\text { Ukuran } \\
\text { Dewan } \\
\text { Komisaris }\end{array}$ & $\begin{array}{l}\text { Jumlah dewan } \\
\text { komisaris yang ada } \\
\text { dalam perusahaan } \\
\text { (Leksono dan Butar, } \\
\text { 2018) }\end{array}$ & $\begin{array}{l}\text { UDK=Jumlah Dewan } \\
\text { Komisaris Perusahaan }\end{array}$ & Rasio \\
\hline $\begin{array}{l}\text { Independensi } \\
\text { Dewan } \\
\text { Komisaris }\end{array}$ & $\begin{array}{l}\text { Proporsi Komisaris } \\
\text { independen dalam } \\
\text { dewan komisaris } \\
\text { (Hutapea dan Malau, } \\
\text { 2018) }\end{array}$ & $\begin{array}{l}\text { IDK }= \\
\frac{\text { Jumlah Komisaris Independen }}{\text { Jumlah Dewan Komisaris }} \times 100 \%\end{array}$ & Rasio \\
\hline $\begin{array}{l}\text { Komite } \\
\text { Audit }\end{array}$ & \multirow{2}{*}{$\begin{array}{l}\text { Sekelompok orang } \\
\text { yang dibentuk untuk } \\
\text { membantu dewan } \\
\text { komisaris, (Fatimah, } \\
\text { et al. 2016) }\end{array}$} & $\begin{array}{l}\text { KA=Jumlah Komite Audit } \\
\text { Perusahaan } \\
\text { KomisarisIndependen dalam KomiteAud }\end{array}$ & \multirow{2}{*}{$\begin{array}{c}\text { Rasio } \\
x 100 \%\end{array}$} \\
\hline & & Jumlah Komite Audit & \\
\hline $\begin{array}{l}\text { Corporate Social } \\
\text { Responsibility } \\
\text { Disclosure }\end{array}$ & $\begin{array}{l}\text { Pengeluaran } \\
\text { informasi yang } \\
\text { ditujukan kepada } \\
\text { pihak yang } \\
\text { berkepentingan } \\
\text { (Restu, et al, 2017) }\end{array}$ & $\begin{array}{l}\mathrm{CSRD}= \\
\frac{\text { Jumlah itemyang diungkapkan }}{91 \text { item }} \times 100 \%\end{array}$ & Rasio \\
\hline ROA & $\begin{array}{l}\text { Rasio yang mengukur } \\
\text { laba perusahaan } \\
\text { dibanding dengan } \\
\text { total aset (Kartini, et }\end{array}$ & $\begin{array}{l}\text { ROA }= \\
\frac{\text { LabaBersihSetelahPajak }}{\text { Total Aset }} \times 100 \%\end{array}$ & Rasio \\
\hline ROE & $\begin{array}{l}\text { Rasio yang mengukur } \\
\text { laba perusahaan } \\
\text { dibanding dengan } \\
\text { total ekuitas (Kartini, } \\
\text { et al, } 2019 \text { ) }\end{array}$ & $\begin{array}{l}\mathrm{ROE}= \\
\frac{\text { LabaBersih Setelah Pajak }}{\text { Total Ekwitas }} \times 100 \%\end{array}$ & Rasio \\
\hline
\end{tabular}

Sumber: Data Diolah (2020)

\section{Analisis Data}

Moderated Regression Analysis digunakan sebagai analisi data penelitian. Variabel yang digunakan dirumuskan kedalam persamaan dibawah ini:

$$
\begin{aligned}
& Y=\alpha+\beta_{1} X_{1}+\beta_{1} X_{2}+\beta_{1} X_{3}+\beta_{2} Z_{1}+\beta_{2} Z_{2}+\beta_{3} X_{1} Z_{1}+\beta_{3} X_{2} Z_{1}+\beta_{3} X_{3} Z_{1}+\beta_{3} X_{1} Z_{2}+ \\
& \beta_{3} X_{2} Z_{2}+\beta_{3} X_{3} Z_{2}+€ \ldots \ldots \ldots \ldots \ldots \ldots \ldots \ldots \ldots \ldots \ldots \ldots \ldots \ldots \ldots \ldots \ldots \ldots \ldots \ldots \ldots \ldots \ldots \ldots \ldots \ldots \ldots \ldots \ldots \ldots \ldots \ldots \ldots \ldots \ldots \ldots \ldots \ldots \ldots \ldots
\end{aligned} \ldots
$$

Keterangan:

$$
\begin{array}{ll}
\mathrm{Y} & =\text { Corporate Social Responsibility Disclosure } \\
\alpha & =\text { Konstanta } \\
\beta_{1} \mathrm{X}_{1} \mathrm{X}_{2} \mathrm{X}_{3} & =\mathrm{UDK}, \text { IDK dan KA } \\
\beta_{2} \mathrm{Z}_{1} \mathrm{Z}_{2} & =\text { ROA dan ROE }
\end{array}
$$


$\beta_{3} \mathrm{X}_{1} \mathrm{Z}_{1} \mathrm{X}_{2} \mathrm{Z}_{1} \mathrm{X}_{3} \mathrm{Z}_{1} \quad=$ Interaksi antara variabel UDK, IDK dan KA dengan ROA

$\beta_{3} \mathrm{X}_{1} \mathrm{Z}_{2} \mathrm{X}_{2} \mathrm{Z}_{2} \mathrm{X}_{3} \mathrm{Z}_{2} \quad=$ Interaksi antara variabel UDK, IDK dan KA dengan ROE

$€$

= Error term

Hipotesis penelitian diujikan dibawah ini:

1. Uji t (Uji Parsial)

Pengujian parsial digunakan untuk membuktikan apakah masing-masing variabel dependen (UDK, IDK dan KA) berpengaruh signifikan terhadap variabel independen (CSRD).

2. Uji F (Uji Simultan)

Pengujian simultan digunakan untuk membuktikan apakah variabel dependen secara simultan berpengaruh signifikan terhadap variabel independen.

3. Uji Moderated Regression Analysis (MRA).

Pengujian MRA dimaksudkan untuk membuktikan apakah model regresi yang digunakan diperkuat atau diperlemah oleh variabel interaksi.

\section{HASIL DAN PEMBAHASAN}

\section{Statistik Deskriptif}

Tabel 3. Statistik Deskriptif

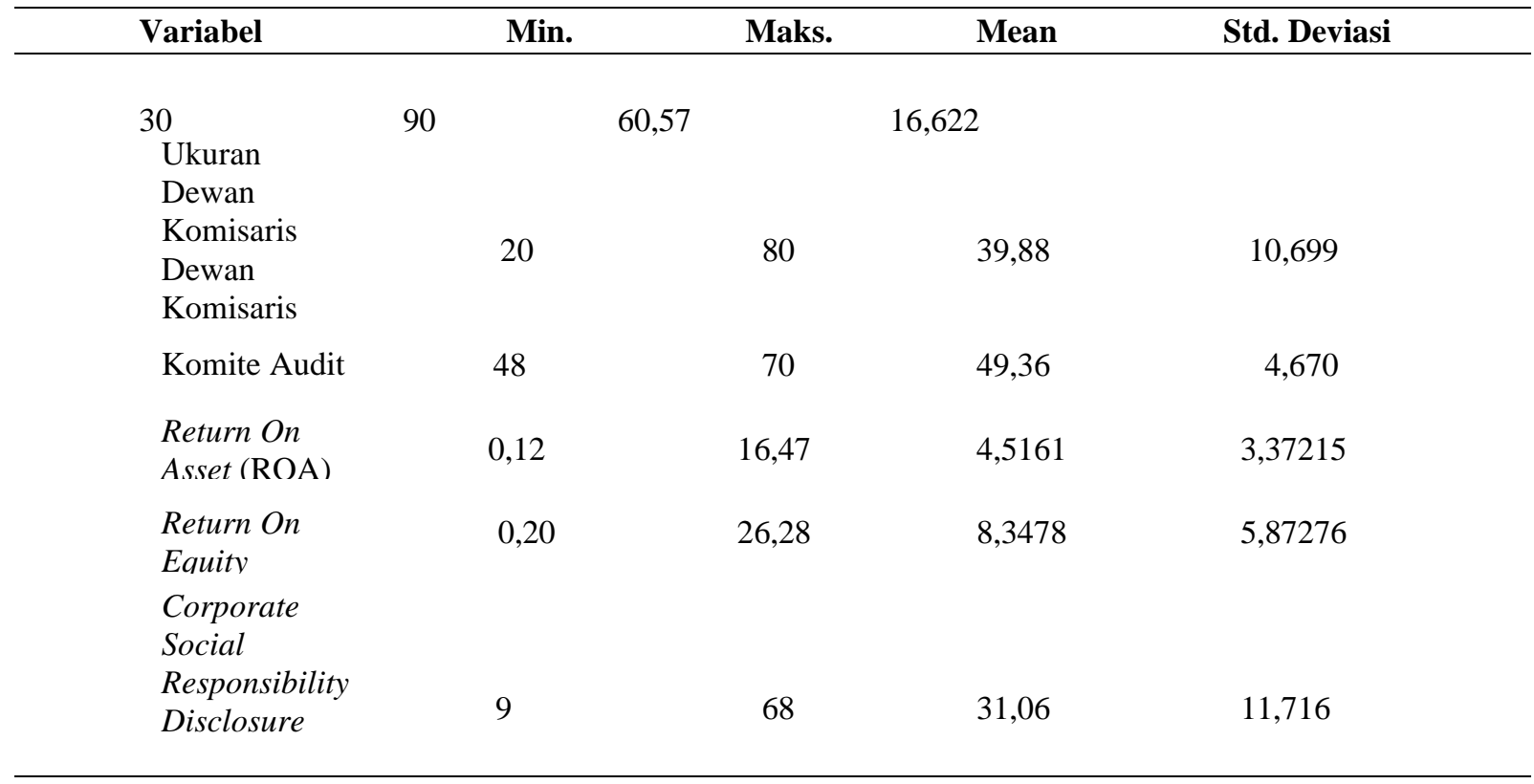

Sumber: Data Diolah (2020) 


\section{Uji Asumsi Klasik}

Tabel 4. Uji Normalitas

Un standardized Residual

Kolmogorov-Smirnov Z

0,976

Asymp. Sig. (2-tailed)

0,297

Sumber: Data Diolah (2020)

Tujuan pengujian normalitas adalah menguji variabel yang dipakai tersebar secara normal atau tidak. Uji Kolmogorov-Smirnov (K-S) dipakai untuk pengujian ini. Berdasarkan tabel IV diketahui bahwa (K-S) sebesar 0,976, karena nilainya diatas 0,05 (K-S>0,05), maka variabel yang dipakai tersebar secara normal.

Tabel 5. Uji Multikoliniearitas

\begin{tabular}{lccc}
\hline Model & \multicolumn{2}{c}{ Collinearity Statistics } \\
& Tolerance & VIF \\
\hline UDK & & \\
IDK & 0,980 & 1,020 \\
KA & 0,972 & 1,029 \\
& 0,961 & 1,041 \\
\hline
\end{tabular}

Sumber: Data Diolah (2020)

Tujuan pengujian multikoliniearitas untuk menguji variabel yang dipakai terjadi korelasi antar variabel independen. Berdasarkan tabel V diketahui nilai tolerance dan nilai VIF variabel UDK sebesar 0,980 dan 1,020. Karena tolerance diatas 0,1 (tolerance $>0,1$ ) dan nilai VIF dibawah 10 (VIF<10), maka variabel UDK tidak terdapat korelasi. Pada variabel IDK diketahui tolerance dan VIF sebesar 0,972 dan 1,029. Karena tolerance diatas 0,1 (tolerance $>0,1)$ dan nilai VIF dibawah 10 (VID<10), maka variabel IDK tidak terdapat korelasi. Variabel KA memiliki tolerance dan VIF sebesar 0,961 dan 1,041. Karena nilai tolerance diatas 0,1 (tolerance $>0,1)$ dan nilai VIF dibawah $10(\mathrm{VIF}<10)$, maka variabel KA tidak terdapat korelasi.

Tabel 6. Heteroskedastisitas

\begin{tabular}{llllll} 
& & UDK & IDK & KA & Unstandardized Residual \\
\cline { 3 - 6 } UDK & Correlation Coefficient & 1,000 & 0,125 & 0,119 & $-0,032$ \\
& Sig. (2-tailed) & & 0,125 & 0,144 & 0,693 \\
& N & 152 & 152 & 152 & 152 \\
& Correlation Coeffiient & 0,125 & 1,000 & 0,054 & 0,054 \\
& Sig. (2-tailed) & 0,125 & & 0,509 & 0,508 \\
& KA & 152 & 152 & 152 & 152 \\
& Correlation Coefficient & 0,119 & 0,054 & 1,000 & 0,062 \\
& Sig. (2-tailed) & 0,144 & 0,509 & & 0,444 \\
& N & 152 & 152 & 152 & 152 \\
& Unstandardized Residual & $-0,032$ & 0,054 & 0,062 & 1,000 \\
& & 0,693 & 0,508 & 0,444 & 152 \\
\hline
\end{tabular}

Sumber: Data Diolah (2020) 
Tujuan pengujian heteroskedastisitas untuk menguji variabel yang digunakan terdapat perbedaan variance pada residual pengamatan yang satu ke pengamatan lainnya. Pengujian ini memakai uji Spearman. Berdasarkan tabel 6 diketahui bahwa pada kolom Unstandardized Residual nilai Sig. (2-tailed) variabel UDK sebesar 0,693. Karena signifikansi diatas 0,05 $(>0,05)$ maka variabel UDK tidak terdapat heteroskedastisitas. Pada variabel IDK memiliki nilai Sig. (2-tailed) sebesar 0,508 pada kolom Unstandaridzed Residual karena signifikansi diatas 0,05 maka variabel IDK tidak terdapat heteroskedastisitas. Sementara pada variabel KA memiliki nilai Sig, (2-tailed) sebesar 0,444 pada kolom Unstandardized Residual, karena signifikansi diatas 0,05 maka variabel KA tidak terdapat heteroskedastisitas.

Tabel 7. Uji Autokorelasi

\begin{tabular}{clllll}
\hline Model & $\mathbf{R}$ & R Square & Adjusted R Square & Std. Error & Durbin-Watson \\
\hline 1 & 0,482 & 0,232 & 0,217 & 10,370 & 1,887 \\
\hline Sumber: & Data & Diolah $(2020)$ & & &
\end{tabular}

Sumber: Data Diolah (2020)

Tujuan pengujian autokorelasi untuk menguji variabel yang dipakai terdapat korelasi. Pengujian ini memakai uji Durbin-Watson (D-W test). Berdasarkan tabel VII diketahui bahwa (D-W) sebesar 1,887 dan diketahui bahwa dL sebesar 1,3177 dan dU sebesar 1,6563, maka dari (D-W) yang dihasilkan dari model regresi ini tidak terjadi autokolerasi karena nilai (D-W) berada diantara nilai dU dan 4-dU $(4-1,6563=2,3437)$ atau $(1,6563<1,887<2,3437)$.

\section{PENGUJIAN HIPOTESIS}

\section{Uji Parsial}

Tabel 8. Coefficient

\begin{tabular}{|c|c|c|c|c|c|}
\hline \multirow[t]{2}{*}{ Model } & \multicolumn{2}{|c|}{ Unstandardized Coefficients } & \multirow{2}{*}{$\begin{array}{c}\text { Standardized Coefficients } \\
\text { Beta }\end{array}$} & \multirow[t]{2}{*}{$\mathbf{t}$} & \multirow[t]{2}{*}{ Sig. } \\
\hline & B & Std. Error & & & \\
\hline (Constan & & 11,526 & 3,213 & 3,587 & 0,000 \\
\hline UDK & 0,323 & 0,051 & 0,458 & 6,302 & 0,000 \\
\hline R Square & 0,209 & & & & \\
\hline
\end{tabular}

Sumber: Data Diolah (2020)

Berdasarkan tabel 8 diketahui bahwa variabel UDK mempunyai nilai $R$ Square sebesar 0,209 artinya hubungan UDK terhadap CSRD dapat menjelaskan sebesar 20,9\% sedangkan nilai sig. 0,000, karena sig. tersebut dibawah 0,05. Maka H1 yang dirumuskan penelitian dapat diterima. Dengan kata lain, banyaknya komposisi dewan komisaris yang ada dalam suatu perusahaan terdapat pengaruh signifikan pada Corporate Social Responsibility Disclosure pada perusahaan subsektor industri dasar dan kimia tahun 2016-2019. 
Penelitian ini sesuai dengan Pasaribu, et al (2015) yang menjelaskan bahwa dewan komisaris merupakan wakil dari investor yang dengan hak yang dimilikinya dapat mendorong keluasan Corporate Social Responsibility Disclosure. Hutapea dan Malau (2018) menyebutkan bahwa hal tersebut dapat memudahkan dewan komisaris dalam memonitor aktivitas perusahaan. Penelitian ini juga didukung oleh penelitian Wiyuda dan Pramono (2017); Mohammadi, et al (2020); Rudyanto dan Siregar (2017); ( Thasya, et al (2020), Yusran, et al (2018) dan Restu, et al (2017). Hasil penelitian ini bertolak dengan penelitian Nurfadilah dan Sagara (2015); Pernamasari (2019); dan Leksono dan Butar (2018) yang menyebutkan bahwa ukuran dewan komisaris berpengaruh tidak signifikan pada Corporate Social Responsibility Disclosure.

Tabel 9. Coefficient

\begin{tabular}{|c|c|c|c|c|c|}
\hline Model & $\begin{array}{l}\text { Unstanc } \\
\text { B }\end{array}$ & $\begin{array}{l}\text { ardized Coefficients } \\
\text { Std. Error }\end{array}$ & $\begin{array}{l}\text { Standardized Coefficients } \\
\text { Beta }\end{array}$ & $\mathbf{t}$ & Sig. \\
\hline (Constant) & 23,390 & 3,634 & & 6,437 & 0,000 \\
\hline IDK & 0,192 & 0,088 & 0,176 & 2,185 & 0,030 \\
\hline R Square & 0,031 & & & & \\
\hline
\end{tabular}

Sumber: Data Diolah (2020)

Berdasarkan tabel 9 diketahui nilai $R$ Square sebesar 0,031 artinya hubungan IDK terhadap CSRD menjelaskan sebesar 3,1\%. Sementara nilai sig. sebesar 0,030 karena nilai sig. dibawah 0,05, maka IDK berpengaruh signifikan pada CSRD. Sehingga H2 yang dirumuskan diterima. Banyaknya proporsi dewan komisaris independen yang ada dalam perusahaan industri dasar dan kimia tahun 2016-2019 berpengaruh signifikan terhadap Corporate Social Responsibility Disclosure.

Penelitian ini berpandangan bahwa dewan komisaris independen memiliki peran yang krusial untuk mendorong independensi dewan komisaris pada shareholder dan menempatkan kepentingan perusahaan sebenar-benarnya diatas kepentingan lain. Sehingga diharapkan dewan komisaris yang terafiliasi berperan secara obyektif dan menaungi stakeholder-nya serta mendorong keluasan Corporate Social Responsibilty Disclosure (Hutapea dan Malau, 2018). Sementara pada penelitian Habbash (2016) menyebutkan bahwa independensi dewan komisaris menjadi bagian terpenting Corporate Governance yang perannya dapat mendukung pemecahan agency cost dan mengedepankan kepentingan para stakeholder, seperti karyawan dan masyarakat lokal. Penelitan ini mendukung penelitian Nazwir, et al (2016); Pasaribu, et al (2015) dan Fatimah, et al (2016). Namun penelitian ini bertolak dengan penelitian Hutapea dan Malau (2018; Putri dan Dwirandra (2018); Restu, et al (2017); Sunarsih dan Nurhikmah (2017) dan Thasya, et al (2020) yang menyebutkan bahwa independensi dewan komisaris tidak berpengaruh signifikan terhadap Corporate Social Responsibility Disclosure. Menurut 
Pernamasari (2019) keberadaaan independensi dewan komisaris bertugas untuk meminimalisir biaya keagenan dan memaksimalkan performa perusahaan dan tidak terkait dengan pengungkapan Corporate Social Responsibility.

Tabel 10. Coefficient

\begin{tabular}{llclll}
\hline Model & \multicolumn{2}{c}{ Unstandardized Coefficients } & Standardized Coefficient & t & Sig. \\
& B & Std. Error & Beta & & \\
\hline (Constant) & 14,994 & 10,070 & & 1,489 & 0,139 \\
KA & 0,325 & 0,203 & 0,130 & 1,602 & 0,111 \\
R Square & 0,017 & & & & \\
\hline
\end{tabular}

Sumber: Data Diolah (2020)

Berdasarkan tabel 10 diketahui bahwa variabel KA mempunyai $R$ Square sebesar 0,017 artinya hubungan antara KA pada CSRD menjelaskan sebesar 1,7\%. Sementara nilai sig. sebesar 0,111, karena nilai sig. diatas 0,05, maka KA tidak berpengaruh signifikan pada CSRD. Dengan demikian H3 yang dirumuskan ditolak. Banyak susunan komite audit yang ada dalam perusahaan industri dasar dan kimia tahun 2016-2019 tidak berpengaruh signifikan pada Corporate Social Responsibility Disclosure.

Peran komite audit yang diharapkan untuk meminimalisir biaya keagenan antara dewan komisaris dengan manajer perusahaan tidak terlaksana dengan baik. Terdapat beberapa alasan yang menjadi dasar, yaitu: Pertama, umunya perseroan di Indonesia memiliki susunan komite audit paling banyak 3 orang sehingga penyusunan komite audit dalam perusahaan terkesan hanya formalitas untuk pemenuhan kebijakan semata (Pasaribu, et al (2015). Kedua, menurut Boshnak (2020) sesuai dengan teori keunggulan kompetitif, dimana perusahaan lebih suka untuk mengurangi informasinya di laporan tahunannya, hal tersebut dapat menjadi ancaman apabila informasi yang menjadi kelemahan perusahaan itu diketahui oleh pesaing.

Penelitian ini bertolak dengan penelitian Nurfadilah dan Sagara (2015); Fatimah, et al (2016); Fadlillah dan Harymawan (2018) dan Restu, et al (2017) yang menyebutkan bahwa banyaknya susunan komite audit yang ada, maka fungsi pengawsan yang dilakukan semakin baik sehingga aktivitas mengenai keluasan Corporate Social Responsibility Disclosure dapat berjalan dengan semestinya. Peran komite audit sangat krusial dalam hal pemeliharaan penyusunan laporan tahunan. Namun, penelitian ini sejalan dengan penelitian Pasaribu, et al (2015); Wiyuda dan Pramono (2017); Thasya, et al (2020); Habbash (2016) dan Boshnak (2020) yang menyebutkan bahwa komite audit berpengaruh tidak signifikan terhadap Corporate Social Responsibility Disclosure. 


\section{Uji Simultan}

Tabel 11. Anova

\begin{tabular}{llllll}
\hline Model & Sum of Square & df & Mean Square & F & Sig. \\
\hline Regression & 4812,177 & 3 & 1604,059 & 14,916 & 0,000 \\
Residual & 15916,290 & 148 & 107,543 & & \\
Total & 0,232 & 151 & & & \\
\hline
\end{tabular}

Sumber: Data Diolah (2020)

Berdasarkan tabel 11 diketahui bahwa nilai sig. 0,000, karena nilai sig. dibawah 0,05, maka UDK, IDK dan KA secara bersama-sama berpengaruh signifikan pada CSRD. Sehingga H4 yang dirumuskan dapat diterima. Hasil penelitian berpandangan bahwa Ukuran Dewan Komisaris, Independensi Dewan Komisaris dan Komite Audit merupakan satu kesatuan komponen yang berada dalam Good Corporate Governance yang secara keseluruhan atau bersama-sama dapat mempengaruhi Corporate Social Responsibility Disclosure perusahaan industri dasar dan kimia tahun 2016-2019.

Good Corporate Governance merupakan instumen yang dipakai guna memastikan manajemen dalam perusahaan berjalan dengan baik, lebih terarah dan terkendali (Jayanti dan Husaini, 2018). Penelitian ini mendukung penelitian Restu, et al (2017) yang menyebutkan bahwa ukuran dewan komisaris, independensi dewan komisaris dan komite audit secara simultan berpengaruh terhadap Corporate Social Responsibility Disclosure.

\section{Uji Moderated Regression Analysis (MRA)}

Tabel 12. Coefficient

\begin{tabular}{|c|c|c|c|c|c|}
\hline \multirow[t]{2}{*}{ Model } & \multicolumn{2}{|c|}{ Unstandardized Coefficients } & \multirow{2}{*}{$\begin{array}{c}\text { Standardized Coefficients } \\
\text { Beta }\end{array}$} & \multirow[t]{2}{*}{$\mathbf{t}$} & \multirow[t]{2}{*}{ Sig. } \\
\hline & B & Std. Error & & & \\
\hline (Constant) & 16,699 & 5,387 & & 3,100 & 0,002 \\
\hline UDK & 0,210 & 0,088 & 0,297 & 4,732 & 0,018 \\
\hline ROA & $-0,973$ & 0,883 & $-0,280$ & $-1,102$ & 0,272 \\
\hline UDK*ROA & 0,001 & 0,001 & 0,426 & 1,537 & 0,126 \\
\hline R Square & 0,231 & & & & \\
\hline
\end{tabular}

Berdasarkan tabel $12 R$ Square variabel Ukuran Dewan Komisaris setelah dimoderasi variabel profitabilitas Return On Asset menjadi 0,231 atau sebesar 23,1\%. Sementara nilai sig. variabel interaksi UDK*ROA diatas 0,05 yaitu sebesar 0,126 yang artinya ROA tersebut tidak dapat memoderasi hubungan antara UDK dengan CSRD. Selain itu, nilai signifikansi variabel ROA terhadap CSRD sebesar 0,272, karena nilai sig. tersebut diatas 0,05 maka variabel tersebut sebagai variabel homologiser moderator. 
Tabel 13. Coefficient

\begin{tabular}{lllcll}
\hline Model & $\begin{array}{c}\text { Unstandardized Coefficients } \\
\text { B }\end{array}$ & $\begin{array}{c}\text { Standardized Coefficients } \\
\text { Beta }\end{array}$ & t & Sig. \\
\hline (Constant) & 14,492 & 7,387 & & 1,962 & 0,052 \\
IDK & 0,389 & 0,189 & 0,355 & 2,061 & 0,041 \\
ROA & 2,125 & 0,457 & 0,612 & 1,459 & 0,147 \\
IDK*ROA & $-0,046$ & 0,036 & $-0,599$ & $-1,277$ & 0,203 \\
R Square & 0,049 & & & & \\
\hline
\end{tabular}

Sumber: Data Diolah (2020)

Berdasarkan tabel $13 R$ Square variabel Independensi Dewan Komisaris setelah dimoderasi dengan variabel Return On Asset menjadi 0,049 atau sebesar 4,9\%. Sementara nilai sig. variabel interaksi IDK*ROA diatas 0,05 yaitu sebesar 0,203 yang artinya variabel ROA tersebut tidak dapat memoderasi hubungan antara IDK dengan CSRD. Selain itu, sig. variabel ROA terhadap CSRD sebesar 0,147, karena sig. diatas 0,05 maka variabel tersebut sebagai homologiser moderator.

Tabel 14. Coefficient

\begin{tabular}{|c|c|c|c|c|c|}
\hline Model & $\begin{array}{c}\text { Unstandardized } \\
\text { B }\end{array}$ & $\begin{array}{l}\text { Coefficients } \\
\text { Std. Error }\end{array}$ & $\begin{array}{c}\text { Standardized Coefficients } \\
\text { Beta }\end{array}$ & $\mathbf{t}$ & Sig. \\
\hline (Constant) & $-5,426$ & 24,348 & & $-0,223$ & 0,824 \\
\hline $\mathrm{KA}$ & 0,715 & 0,500 & 0,285 & 1,430 & 0,155 \\
\hline ROA & 0,011 & 3,686 & 1,082 & 1,020 & 0,310 \\
\hline $\mathrm{KA} * \mathrm{ROA}$ & 3,759 & 7,518 & $-1,027$ & $-0,932$ & 0,353 \\
\hline R Square & 0,032 & & & & \\
\hline
\end{tabular}

Sumber: Data Diolah (2020)

Berdasarkan tabel $14 R$ Square variabel Komite Audit setelah dimoderasi dengan variabel Return On Asset menjadi 0,032 atau sebesar 3,2\%. Sementara nilai sig. variabel interaksi KA*ROA diatas $0,05 \%$ yaitu sebesar 0,353 yang artinya variabel ROA tersebut tidak dapat memoderasi hubungan antara KA dengan CSRD. Selain itu, sig. variabel ROA terhadap CSRD sebesar 0,310, karena sig. diatas 0,05 maka variabel tersebut sebagai homologiser moderator.

Tabel 15. Coefficient

\begin{tabular}{|c|c|c|c|c|c|}
\hline Model & $\begin{array}{c}\text { Unstan } \\
\text { B }\end{array}$ & $\begin{array}{l}\text { dized Coefficient } \\
\text { Std. Error }\end{array}$ & $\begin{array}{c}\text { Standardized Coefficients } \\
\text { Beta }\end{array}$ & $\mathbf{t}$ & Sig \\
\hline (Constant) & 22,223 & 5,641 & & 3,94 & ,000 \\
\hline UDK & 0,139 & 0,091 & 0,197 & 1,534 & 0,127 \\
\hline ROE & $-1,331$ & 0,602 & $-0,667$ & $-2,210$ & 0,029 \\
\hline $\mathrm{UDK}^{*} \mathrm{ROE}$ & 0,022 & 0,099 & 0,803 & 2,402 & 0,018 \\
\hline R Square & 0,240 & & & & \\
\hline
\end{tabular}

Sumber: Data Diolah (2020)

Berdasarkan tabel $15 R$ Square variabel Ukuran Dewan Komisaris setelah dimoderasi variabel Return On Equity menjadi sebesar 0,273 atau 27,3\%. Sementara nilai sig. variabel 
interaksi UDK*ROE dibawah 0,05 yaitu sebesar 0,023. Artinya variabel ROE dapat memoderasi hubungan antara UDK dengan CSRD. Selain itu, sig. variabel ROE terhadap CSRD sebesar 0,029, karena sig. dibawah 0,05 maka variabel tersebut sebagai quasi moderator.

Tabel 16. Coefficient

\begin{tabular}{|c|c|c|c|c|c|}
\hline \multirow{2}{*}{ Model } & \multicolumn{2}{|c|}{ Unstandardized Coefficient } & \multirow{2}{*}{$\begin{array}{l}\text { Standardized Coefficients } \\
\text { Beta }\end{array}$} & \multirow[t]{2}{*}{$\mathbf{t}$} & \multirow[t]{2}{*}{ Sig. } \\
\hline & B & Std. Error & & & \\
\hline (Constant) & 22,716 & 8,015 & & 2,834 & 0,005 \\
\hline IDK & 0,177 & 0,206 & 0,162 & 1,502 & 0,390 \\
\hline ROE & 1,555 & 0,880 & 0,078 & 1,113 & 0,860 \\
\hline IDK*ROE & $-9,490$ & 0,022 & 0,000 & 0,000 & 1,000 \\
\hline R Square & 0,037 & & & & \\
\hline
\end{tabular}

Sumber: Data Diolah (2020)

Berdasarkan tabel $16 R$ Square variabel Independensi Dewan Komisaris setelah dimoderasi variabel Return On Equity menjadi sebesar 0,008 atau sebesar 0,8\%. Sementara nilai sig. variabel interaksi IDK*ROE diatas 0,05 yaitu sebesar 0,955 . Artinya variabel ROE tidak dapat memoderasi hubungan antara IDK dengan CSRD. Selain itu, sig. variabel ROE terhadap CSRD sebesar 0,860, karena sig. diatas 0,05 maka variabel tersebut sebagai homologiser moderator.

Tabel 17. Coefficient

\begin{tabular}{llllll}
\hline Model & \multicolumn{2}{c}{ Unstandardized Coefficient } & Standardized Coefficients & t & Sig. \\
& B & Std. Error & Beta & & \\
\hline (Constant) & $-9,386$ & 25,823 & & $-0,363$ & 0,717 \\
KA & 0,797 & 0,531 & 0,318 & 1,502 & 0,135 \\
ROE & 2,352 & 2,114 & 1,180 & 1,113 & 0,267 \\
KA*ROE & $-4,459$ & 4,322 & $-1,140$ & $-1,032$ & 0,304 \\
R Square & 0,032 & & & & \\
\hline
\end{tabular}

Sumber: Data Diolah (2020)

Berdasarkan tabel $17 R$ Square variabel Komite Audit setelah dimoderasi variabel Return On Equity menjadi sebesar 0,032 atau sebesar 3,2\%. Sementara nilai sig. variabel interaksi IDK*ROE diatas 0,05 yaitu sebesar 0,303. Artinya variabel ROE tidak dapat memoderasi hubungan antara KA dengan CSRD. Selain itu, sig. variabel ROE terhadap CSRD sebesar 0,267, karena nilainya diatas 0,05 maka variabel tersebut sebagai homologiser moderator.

Berdasarkan tabel 17 dapat diketahui bahwa sig. variabel interaksi antara variabel ukuran dewan komisaris dengan Return On Asset terhadap Corporate Social Responsibility disclosure adalah sebesar 0,126 . Hal ini membuktikan dengan adanya peningkatan laba yang terjadi karena efektivitas pengelolaan aset tidak mendorong dewan komisaris perusahaan dalam mengungkapan tanggung jawab sosialnya. Maka h5a yang dirumuskan dalam penelitian ini ditolak. Hal ini dapat terjadi karena perusahaan kini mulai sadar akan 
pentingnya pengungkapan tanggung jawab sosial tanpa harus memperjelas keterangan aset dan laba yang dimilikinya (Subara dan Saragih, 2020). Sementara menurut Boshnak (2020) pada dasarnya kegiatan CSR itu memerlukan biaya yang cukup besar sehingga hal tersebut tentu saja mengurangi pendapatan yang ada.

Berdasarkan tabel 15 dapat diketahui bahwa sig. variabel interaksi antara variabel ukuran dewan komisaris dengan Return On Equity terhadap Corporate Social Responsibility Disclosure sebesar 0,018. Hal ini membuktikan bahwa variabel Return On Equity mampu memoderasi variabel ukuran dewan komisaris dengan Corporate Social Responsibility perusahaan industri dasar dan kimia tahun 2016-2019. Hal tersebut menandakan bahwa dewan komisaris dalam melakukan aktivitas pengungkapan tanggung jawab sosialnya dipengaruhi oleh ekuitas perusahaan. Karena perusahaan ingin menunjukkan motifnya kepada para investor, sebab rasio Return On Equity merupakan rasio yang penting bagi shareholder untuk mengetahui keefektivitas dan keefisiensi pengelolaan modal sendiri (Kartini, et al (2019). Sehingga para investor merasa lebih percaya lagi untuk menanamkan modalnya. Maka h5d yang dirumuskan dalam penelitian ini diterima. Hasil penelitian ini sesuai dengan teori stakholder yang menyebutkan bahwa perusahaan bukan hanya sebuah entitas bisnis semata, namun juga memperhatikan kepentingan para stakeholdernya.

Berdasarkan tabel 13 dan tabel 16 dapat diketahui sig. variabel interaksi antara variabel independensi dewan komisaris dengan variabel Return On Asset dan Return On Equity terhadap Corporate Social Responsibility Disclosure berturut-turut sebesar 0,203 dan 1,000. Karena nilai sig. tersebut lebih dari 0,05, hal ini menandakan bahwa kedua hasil interaksi variabel tersebut tidak dapat memoderasi hubungan antara variabel independensi dewan komisaris dengan Corporate Social Responsibility Disclosure. Hasil peneltiian ini berpandangan bahwa karena dewan komisaris independen merupakan dewan perusahaan yang tidak terafiliasi, maka kegiatan operasi sehari-harinya tidak didorong oleh profitabilitas perusahaan. Maka h5b dan h5e yang dirumuskan ditolak.

Berdasarkan tabel 14 dan tabel 17 dapat diketahui sig. variabel interaksi antara variabel komite audit dengan variabel Return On Asset dan Return On Equity terhadap Corporate Social Responsibility Disclosure adalah berturut-turut sebesar 0,353 dan 0,304. Maka h5c dan h5f yang dirumuskan ditolak. Hal ini menandakan bahwa kedua hasil interaksi variabel tersebut tidak dapat memoderasi hubungan antara variabel komite audit dengan Corporate Social Responsibility Disclosure. Penelitian ini bertolak dengan teori stakeholder yang menyebutkan pelaporan tanggung jawab sosial merupakan salah satu cara untuk meningkatkan kepercayaan stakeholder. Hal tersebut dikarenakan komite audit yang ada 
hanya sebatas memantau apakah operasional perusahaan berjalan sesuai dengan peraturan atau tidak sehingga kinerjanya tidak didorong oleh profitabilitas (Putra dan Nuzula, 2017).

\section{KESIMPULAN DAN SARAN}

Berdasarkan hasil analisis tersebut maka ditarik kesimpulan dibawah ini:

1. Secara parsial variabel ukuran dewan komisaris dan independensi dewan komisaris memiliki pengaruh yang signifikan pada Corporate Social Responsibility Disclosure sedangkan variabel komite audit berpengaruh tidak signifikan. Secara simultan variabel tersebut berpengaruh signifikan pada Corporate Social Responsibility Disclosure.

2. Pada uji moderasi Return On Asset menunjukkan hasil bahwa variabel tersebut tidak dapat memoderasi hubungan antara variabel independen dengan variabel dependen. Sementara pada ujia moderasi Return On Equtiy diketahui bahwa variabel tersebut mampu memoderasi hubungan antara variabel ukuran dewan komisaris dengan Corporate Social Responsibility Disclosure.

Keterbatasan pada penelitian ini adalah analisis ukuran dewan komisaris, independensi dewan komisaris dan komite audit yang masih sangat sederhana. Hal tersebut ditunjukkan dengan nilai $R$ Square yang kurang dari 50\% pada masing-masing variabel. Selain itu, variabel moderasi yang digunakan hanya berfokus pada rasio profitabilitas. Saran untuk penelitian berikutnya adalah penambahan variabel moderasi menggunakan rasio yang lain seperti leverage ratio, dimana rasio tersebut memungkinkan memiliki pengaruh terhadap pengungkapan tanggung jawab sosial perusahaan dan juga objek penelitian menggunakan perusahaan pada sektor-sektor lainnya. Berdasarkan hasil penelitian ini diharapkan dapat menumbuhkan kesadaran para pemangku kepentingan akan pentingnya peran dan tugas dewan perusahaan sehingga lebih kompeten lagi dalam melaksanakan kewajibannya salah satunya mengenai pengungkapan tanggung jawab sosial yang dilakukan. Seperti yang diketahui, pengungkapan bertujuan untuk mengkomunikasikan dan menghubungkan perusahaan dengan para stakeholdernya dan tentu saja informasi-informasi yang diungkapkan harus faktual sebab informasi-informasi tersebut tentu saja dapat dijadikan referensi para investor dan calon investor untuk berinvestasi.

\section{REFERENSI}

Boshnak, H. (2020). Determinants of Corporate Social Responsibility and Voluntary Disclosure in Saudi Listed Firms. Journal of Financial Reporting and Accounting.

Fadlillah, R. N., dan Iman H. (2018). Pengungkapan Perusahaan di Indonesia: Governance dan Struktur Kepemilikan. Jurnal Akuntansi dan Keuangan Indonesia, 3 (1), 63-75.

Fatimah, S. M., \& Fenny T. (2016). Pengaruh Komisaris Independen dan Komite Audit 
terhadap Pengungkapan Corporate Social Responsibility Perusahaan Pertambangan di Bursa Efek Indonesia Periode 2012 s.d 2014. Jurnal Online Mahasiswa, 3 (2), 1-11.

Furi, A. N. (2020) Peran Diversitas Gender dalam Memoderasi Pengaruh Ukuran Perusahaan dan Profitabilitas terhadap Pengungkapan Islamic Social Reporting. Skripsi. Fakultas Ekonomi UIN Maulana Malik Ibrahim Malang.

Gassing, S.., dan Suryanto. (2016). Public Relation. Yogyakarta: Andi Offset.

Habbash, M. (2016). Corporate Governance and Corprorate Social Responsbility Disclosure: Evidence from Saudi Arabia. Journal Social Responsibility, 12 (4), 740-754.

Hutapea, H. D., dan Elissa Lolita M. (2018). Pengaruh Praktek Good Corporate Governance (GCG) terhadap Pengungkapan Corporate Social Responsibility (Studi Kasus Perusahaan Perbankan yang Terdaftar di Bursa Efek Indonesia). Jurnal Ilmiah Skylandsea, 2 (2), 278-291.

Jayanti, K. R., dan Achmad H. (2018). Pengaruh Good Corporate Governance dan Profitabilitas terhadap Pengungkapan Corporate Social Responsibility. Jurnal Administrasi Bisnis, 59 (1), 16-22.

Khasanah, I. D. (2020). Pengaruh Corporate Social Responsibility (CSR) dan Good Corporate Governance (GCG) terhadap Nilai Perusahaan dengan Profitabilitas sebagai Variabel Intervening. Skripsi. Fakultas Ekonomi UIN Maulana Malik Ibrahim Malang.

Leksono, A. A., dan Sansaloni B. B. (2018). Pengaruh Good Corporate Governance dan Karakteristik Perusahaan terhadap Pengungkapan Corporate Social Responsibility. Jurnal Akuntansi Bisnis, 16 (1), 1-18.

Mohammadi, S.., Hadi S., dan Nader N. (2020). The Impact of Board and Audit Committee Characteristic on Corporate Social Responisiblity: Evidence for The Iranian Stock Exchange. International Journal of Productivity and Peformance Management.

Nazwir, I., Yeassy D., dan Herawati. (2016). Pengarh Kepemilikan Institusional, Komposisi Dewan Komisaris dan Kinerja Perusahaan terhadap Luas Pengungkapan Corporate Social Responsibility dalam Sustainability Report pada Perusahaan Pertambangan di Bursa Efek Indonesia. Jurnal Fakultas Ekonomi, 8 (1), 1-14.

Nurfadilah, W., dan Yusar S. (2015). Pengaruh Good Corporate Governance, Karakteristik Perusahaan dan Regulasi Pemerintah terhadap Pengungkapan Corporate Social Responsibility. Jurnal Akuntabilitas, 8 (1), 78-89.

Pasaribu, R. B. F., Dionysia K., dan Dian K. (2015). Pengaruh Earning Management dan Mekanisme Good Corporate Governance terhadap Pengungkapan Corporate Social Responsibility pada Emiten Manufaktur di Bursa Efek Indonesia. Jurnal Riset Manajemen dan Bisnis, 10 (2), 97-121.

Pernamasari, R. (2019). The Effect of Elements Good Corporate Governance on Disclosure of Social Responsibility: Study of the Indonesian Kompas 100 Indexed Companies. Scholars Journal of Economics, Business and Management, 6 (7), 336-344.

Putri, W. R., dan Anak A. N. B. D. (2018). Pengaruh Profitabilitas pada Pengungkapan Corporate Social Responsibility dengan Good Corporate Governnance dan Leverage sebagai Variabel Pemoderasi. Jurnal Buletin Studi Ekonomi, 23 (1), 46-60.

Restu, M., Willy S. Y. \& Annisa N. (2017). Pengaruh Ukuran Dewan Komisaris, Proporsi Dewan Komisaris Independen dan Ukuran Komite Audit terhadap Pengungkapan Corporate Social Responsibility. Proceeding of Management, 4 (3), 2742-2749.

Rudyanto, A., dan Sylvia V. S. (2017). The Effect of Stakeholder Pressure and Corporate Governance on The Sustainability Report Quality. International Journal of Ethics and Sytems, 34 (2), 233-249.

Saputra, S. E. (2016). Pengaruh Leverage, Profitabilitas dan Size Perusahaan terhadap Pengungkapan Corporate Social Responsibility pada Perusahaan di Bursa Efek Indonesia. Journal of Economic and Economic Education, 5 (1), 75-89. 
Sarafina, S.., dan Muhammad S. (2017). Pengaruh Good Corporate Governance terhadap Kinerja Keuangan dan Perusahaan. Jurnal Akuntansi Bisnis, 50 (3), 108-117.

Suastha, R. D. (Juli 2016). Riset Temukan Kualitas CSR Perusahaan Indonesia Rendah. $\begin{array}{lllll}\text { Diperoleh } & 3 & \text { Agustus } & 2020 & \text { dari }\end{array}$ https://www.cnnindonesia.com/nasional/20160721074144-20-146030/riset-temukankualitas-csr-perusahaan-indonesia-rendah.

Sugiyono. (2012). Metode Penelitian Kuantitatif, Kualitatif dan R\&D. Bandung: Alfabeta.

Sunarsih, U., dan Nurhikmah. (2017). Determinants of The Corporate Social Responsibility Disclosure. Etikonomi, 16 (2), 161-172.

Sunyoto, D. (2013). Metodologi Penelitian Akuntansi. Bandung: Refika Aditama.

Sutedi, A. (2011). Good Corporate Governance. Jakarta: Sinar Grafika.

Thasya, N., Lisah., Angeline., Natasyah G., Veronica., \& Namira U. R. (2020). Pengaruh Good Corporate Governance terhadap Corporate Social Responsibility pada Perusahaan Sub Sektor Transportasi. Jurnal Samudra Ekonomi dan Bisnis, 11 (1), 69-82.

Wahyuandari, W. (2015). Pengaruh Tingkat Profitabilitas Perusahaan terhadap Pengungkapan CSR Perusahaan. Jurnal Universitas Tulungagung Bonorowo, 2 (2).

Wiyuda, A., dan Hadi P. (2017). Pengaruh Good Corporate Governance, Karakteristik Perusahaan terhadap Luas Pengungkapan Corporate Social Responsibility pada Perusahaan Terdaftar di BEI. Kompartemen, 15 (1), 12-25.

Yanto, N. (Januari 2012). Dukungan Pemerintah Dalam Pelaksanaan CSR. Diperoleh 2 April 2021 dari https://www.neraca.co.id/article/8583/dukungan-pemerintah-dalampelaksanaan-csr.

Yusran, I. A. R., Farida T. K., dan Wiwin A. (2018). Pengaruh Indikator Good Corporate Governance terhadap Corporate Social Responsbility Disclosure. Proceeding of Management, 5 (1), 621-627.

Yusuf, M. Y. (2017). Islamic Corporate Responsibility Pada Lembaga Keuangan Syariah Teori dan Praktik. Depok: Kencana. 